Leszek PAWLIKOWICZ

Uniwersytet Rzeszowski ${ }^{1}$

Instytutu Nauk o Polityce

lpawlik@ur.edu.pl

ORCID 0000-0002-4389-1937

https://doi.org/10.34739/dsd.2020.01.11

\title{
STRUKTURY KGB NA BLISKIM WSCHODZIE \\ W LATACH 1954-1991. RETROSPEKCJA \\ I JEJ WSPÓŁCZESNE IMPLIKACJE
}

\begin{abstract}
ABSTRAKT: W artykule zaprezentowano w zarysie podstawowe struktury Komitetu Bezpieczeństwa Państwowego (przy Radzie Ministrów) ZSRR prowadzące działania operacyjne na terenie trzynastu państw Bliskiego Wschodu ze szczególnym uwzględnieniem: Libanu, Egiptu, Syrii, Iraku oraz Jemenu Północnego i Południowego. Ponadto przedstawiono specyfikę regionu, a także jej oddziaływanie na profil podejmowanych tam przedsięwzięć, zwłaszcza w zakresie operacji realizowanych w ramach jednostek organizacyjnych 1. Zarządu Głównego KGB odpowiedzialnego za prowadzenie wywiadu zagranicznego, jak również ich możliwy wpływ na późniejsze działania Służby Wywiadu Zagranicznego FR na tym obszarze.
\end{abstract}

SŁOWA KLUCzowe: wywiad, KGB, SWR, Bliski Wschód, terroryzm

\section{STRUCTURES OF THE KGB IN THE MIDDLE EAST BETWEEN 1954 AND 1991. RETROSPECTION AND ITS CONTEMPORARY IMPLICATIONS}

\begin{abstract}
The article outlines the basic structures of the State Security Committee (attached to the Council of Ministers) of the USSR carrying out operational activities in thirteen countries of the Middle East with particular emphasis: Lebanon, Egypt, Syria, Iraq and North and South Yemen. Moreover, the specificity of the region was presented, as well as its impact on the profile of events undertaken there, especially in the scope of operations carried out within the organizational units of the 1 st Chief Directorate of the KGB responsible for conducting foreign intelligence, as well as their possible impact on the subsequent activities of the Foreign Intelligence Service of the Russian Federation in this area.
\end{abstract}

KEYWORDS: intelligence, KGB, SVR, Middle East, terrorism

\footnotetext{
${ }^{1}$ University of Rzeszów; Poland.
} 


\section{WSTĘP}

Funkcjonowanie struktur Komitetu Bezpieczeństwa Państwowego (przy Radzie Ministrów) ZSRR [ros. Комитет государственной безопасности (при Совете Министров СССР) КГБ при СM CCCP] w regionie bliskowschodnim stało się, jak na razie, przedmiotem stosunkowo niewielkiej liczby opracowań naukowych (mimo przywołanych w dołączonym na końcu niniejszego artykułu spisie pozycji bibliograficznych należy wszelako w tym miejscu podkreślić wyjątkowe znaczenie jednej $\mathrm{z}$ dwóch monografii opracowanej przez Wasilija Mitrochina na podstawie jego zapisków $\mathrm{z}$ archiwum wywiadu zagranicznego KGB, a przy współpracy z brytyjskim historykiem Christopherem Andrew ${ }^{2}$ ). Ze względu jednak na rozległość przedmiotowo-chronologiczną i wielowątkowość zagadnienia niniejszy artykuł siłą rzeczy musi ograniczyć się jedynie do bardzo wstępnego zarysu tematyki.

Zasadniczym problemem badawczym było uzyskanie odpowiedzi na pytania, jakie struktury KGB prowadziły działania operacyjne w przywołanym regionie, jaka była skala i zasadnicze kierunki ich działań, a także w jakim zakresie ich ówczesne operacje mogą mieć wpływ na późniejsze działania Służby Wywiadu Zagranicznego FR (ros. Служба Внешней Разведки РФ-CВР $Р \Phi)$ na tym obszarze.

Na potrzeby przyjąłem założenia temporalne oparte wprost na okresie funkcjonowania Komitetu Bezpieczeństwa Państwowego (przy Radzie Ministrów) ZSRR, czyli od 13 marca 1954 roku do 22 października 1991 roku, a w przypadku SWR aż do chwili obecnej³

$\mathrm{Z}$ kolei $\mathrm{w}$ ramach założeń terytorialno-geograficznych, na podstawie definicji wprowadzonej w 1964 r. przez amerykański Departament Stanu, a w rezultacie także i przez zdecydowaną większość zachodnich ekspertów zajmujących się tym regionem (w tym $\mathrm{m}$. in. Profesor Galię Golan, niekwestionowanego eksperta w sprawach relacji radzieckobliskowschodnich), przyjąłem, iż pojęcie „Bliskiego Wschodu” obejmuje ogółem 17 państw położonych na styku trzech kontynentów, to jest: Turcję, Syrię, Liban, Izrael, Egipt, Jordanię, Irak, Arabię Saudyjską, Północny i Południowy Jemen, Oman, Zjednoczone Emiraty Arabskie, Katar, Bahrajn, Kuwejt, Iran i Afganistan ${ }^{4}$.

Jednakowoż z dwóch istotnych powodów wyłączyłem z niniejszej, krótkiej analizy cztery (spośród wspomnianych 17) kraje - Turcję, Izrael, Iran i Afganistan, gdyż: po pierwsze, ze względów etnicznych przeważała tam (i nadal przeważa) ludność niearabska,

\footnotetext{
${ }^{2}$ C. Andrew, W. Mitrochin, Archiwum Mitrochina II: KGB i świat, Poznań 2006.

3 Pomiędzy 13 marca 1954 r. a 5 lipca 1978 r. wspomniana struktura funkcjonowała pod nazwą „Komitet Bezpieczeństwa Państwowego przy Radzie Ministrów ZSRR” (Комитет государственной безопасности при Совете Министров СССР - КГБ при СМ СССР), natomiast od 5 lipca 1978 r. do 22 października 1991 r. działała pod nazwą „Komitet Bezpieczeństwa Państwowego ZSRR” (Комитет государственной безопасности СССР КГБ СССР). Zob. m. in.: Лубянка. Органы ВЧК-ОГПУ-НКВД-НКГБ-МГБ-МВД-КГБ 1917-1991. Справочник (opr. А. Кокурин, Н. Петров), Международный Фонд »Демократиящ, Москва 2003, s. 149, 172; A. Knight, The KGB. Police and Politics in the Soviet Union, Boston-London-Sydney 1988, s. 116.

${ }^{4}$ G.E. Pearcy, The Middle East. An Indefinable Region, Washington D.C. June 1964, s. 2-3 (wizualizacja regionu na mapie) oraz s. 12 (wnioski); G. Golan, Soviet Policies in the Middle East. From World War II to Gorbachev, Cambridge-New York-Melbourne-Sydney 1991, s. IX i okładka (mapy identyczne z definicją przyjętą przez Departament Stanu w czerwcu 1964 r).
} 
a po drugie, ich ówczesne sojusze rzutujące na zimnowojenną równowagę sił przez większą część wspomnianego okresu nie tylko nie wpływały na tworzenie coraz mocniejszych powiązań z pozostałymi państwami tegoż regionu, lecz także ustawiały je w roli antagonistów wspomnianej ,trzynastki" ${ }^{5}$.

\section{RÓŻNORODNOŚĆ STRUKTUR KGB NA BLISKIM WSCHODZIE}

W ramach struktur Komitetu Bezpieczeństwa Państwowego (przy Radzie Ministrów) ZSRR istniało kilka odrębnych pionów (w randze co najmniej samodzielnych zarządów), które niezależnie od siebie utrzymywały na Bliskim Wschodzie swoich własnych funkcjonariuszy realizujących rozmaite działania operacyjne. Poza 1. Zarządem Głównym KGB odpowiedzialnym za prowadzenie szeroko rozumianego wywiadu zagranicznego, zwłaszcza agenturalnego, odnosiło się to w szczególności do 8. Zarządu Głównego (ds. kryptografii i dekryptażu) KGB, a następnie, wyodrębnionego z jego struktury w czerwcu 1973 r., 16. Zarządu (ds. wywiadu sygnałowego) KGB. Oba zajmowały się m. in. nasłuchem łączności prowadzonym $\mathrm{z}$ terenu legalnych rezydentur zagranicznych komitetu ${ }^{6}$. W ten sposób według opinii Mitrochina - zdołano pozyskać więcej informacji dotyczących Bliskiego Wschodu niż łącznie ze wszystkich źródeł agenturalnych wywiadu zagranicznego ${ }^{7}$.

Wyjątkowo ważną rolę $\mathrm{w}$ tamtym regionie odgrywał też 3. Zarząd Główny (ds. kontrwywiadu wojskowego) $\mathrm{KGB}^{8}$, którego funkcjonariusze pełnili służbę w radzieckich jednostkach wojskowych oraz zespołach doradców wojskowych (obecnych w różnych okresach czasu) na terytorium Egiptu, Syrii, Iraku oraz Północnego i Południowego Jemenu realizując zadania wynikające z tzw. ochrony kontrwywiadowczej9.

\footnotetext{
${ }^{5}$ Vide: D. Corn, Bliski Wschód wogniu. Oblicza konfliktu 1956-2003, Warszawa 2003, s. 141 i n.

${ }^{6}$ Vide: Лубянка. Органы ВЧК-ОГПУ ..., s. 150, 171, 171; Д. Прохоров, Разведка от Сталина до Путина, Нева, Санкт-Петербург 2005, s. 267, 271-272; D. Ball, Soviet Signals Intelligence (SIGINT), Canberra 1989, s. 38-39. Wiadomo, że najwcześniej uruchomiono punkty nasłuchu w Kairze i Damaszku, które nosiły kryptonimy (odpowiednio) „Orion” i „Sigma”. Według danych z 1989 r. urządzenia nasłuchu elektronicznego były zamontowane na terenie radzieckich ambasad znajdujących się w stolicach zaledwie sześciu z trzynastu poddanych analizie krajów. Poza Egiptem i Syrią zlokalizowano je w Libanie (Bejrut), Iraku (Bagdad), Kuwejcie (al-Kuwait) oraz Jemenie Południowym (Aden). Vide: D. Ball, Soviet Signals Intelligence..., s. 40-42; Д. Прохоров, Разведка от Сталина..., s. 272-273; C. Andrew, W. Mitrochin, Archiwum Mitrochina II..., s. 189.

${ }^{7}$ C. Andrew, W. Mitrochin, Archiwum Mitrochina II..., s. 173. Zgodnie z danymi zebranymi przez Mitrochina dzięki skutecznie działającemu dekryptażowi udawało się odczytywać (przekazywane drogą radiową) depesze dyplomatyczne Egiptu, Syrii, Południowego Jemenu (czyli Ludowo-Demokratycznej Republiki Jemenu). Vide: ibidem, s. 174, 250.

${ }^{8}$ Pomiędzy lutym 1960 r. a czerwcem 1982 r. jego status obniżono do rangi 3. Zarządu KGB.

9 Vide: Лубянка. Органы ВЧК-ОГПУ..., s. 150, 159, 173. Radzieccy doradcy wojskowi pojawili się we wspomnianych krajach już w połowie lat pięćdziesiątych, choć w niewielkiej liczbie, a ich obecność w części przypadków (np. Jemenie Północnym) nie miała jeszcze charakteru permanentnego (zajmowali się bowiem szkoleniem tamtejszych sił zbrojnych w obsłudze systemów uzbrojenia dostarczanego z ZSRR). Najwcześniej przybyli do Egiptu (w 1955 r., a druga fala trafiła tam we wrześniu 1956 r.; wiadomo także o ich pobycie w tym kraju pomiędzy październikiem 1962 r. a majem 1963 r. oraz w 1966 r.), Syrii (ogólnie wskazuje się na lata 1955-1956), Jemenu Północnego (przebywali tam od listopada 1956 r. do sierpnia 1957 r., po czym powrócili na stałe najpóźniej w październiku 1962 r.) i Iraku (w 1958 r.). Najpóźniej natomiast trafili do Jemenu Południowego (w styczniu 1968 r.). W rezultacie tzw. wojny sześciodniowej do Egiptu i Syrii skierowano ponadto regularne jednostki lotnicze i obrony powietrznej sił zbrojnych ZSRR, a liczba radzieckich doradców
} 
Podobne funkcje, choć w odniesieniu do sfery cywilnej, wykonywali oficerowie 2. Zarządu Głównego (ds. kontrwywiadu krajowego) KGB, którzy poza monitoringiem wszelkiego rodzaju wyjazdów obywateli ZSRR do krajów tego regionu zajmowali się także fizyczną i agenturalną penetracją (zlokalizowanych w Moskwie) bliskowschodnich placówek dyplomatycznych oraz, choć w mniejszym zakresie, pozyskiwaniem informacji od zwerbowanych podczas pobytu w ZSRR obywateli tych państw ${ }^{10}$.

\section{STRUKTURY WYWIADU ZAGRANICZNEGO KGB W REGIONIE}

W ramach 1. Zarządu Głównego KGB koordynacją działalności wywiadowczej wobec wspomnianych państw zajmowały się w moskiewskiej centrali następujące jednostki organizacyjne: 4. Wydział (tzw. wschodni), który wkrótce przemianowano na 8 . Wydział (tzw. bliskowschodni), a od lat siedemdziesiątych dodatkowo wydziały: 18. (tzw. arabski) i 20. (tzw. pion współpracy z zaprzyjaźnionymi krajami Trzeciego Świata) ${ }^{11}$. Podlegały im legalne rezydentury wywiadowcze lub przedstawicielstwa prowadzące operacje $\mathrm{z}$ terenu gmachów radzieckich ambasad, konsulatów, misji handlowych, a w mniejszym zakresie biur linii lotniczych i przedsiębiorstw przemysłowych czy handlowych. Ogółem w pierwszej połowie lat siedemdziesiątych XX wieku liczba oficerów 1. Zarządu Głównego KGB operujących jedynie pod tzw. przykryciem dyplomatycznym z terenu oficjalnych placówek dyplomatycznych w wymienionych krajach regionu (bez uwzględnienia Turcji, Iranu

wojskowych znacznie wzrosła we wszystkich krajach regionu (najwięcej przebywało ich w 1972 r. w Egipcie ok. 15-20 tys.). Z wyjątkiem Egiptu, który w lipcu 1972 r. zdecydował się na wydalenie radzieckich jednostek i doradców (ze względu na liczne werbunki oraz próby werbunków przedstawicieli egipskich władz przez KGB i GRU), ich obecność w Syrii, obu państwach jemeńskich (zjednoczonych w maju 1990 r.), jak również w Iraku (również po tzw. I wojnie w Zatoce Perskiej, kiedy to w ramach sił ONZ przebywali obserwatorzy wojskowi ZSRR) trwała aż do rozpadu Związku Radzieckiego. Zob. szerzej: Central Intelligence Agency, Annex to Watch Committee Report No. 319, SC 00358/56, 12 September 1956 https://history.state.gov/ historicaldocuments/frus1955-57v16/d214 (14.01.2020); idem, Soviet Military Presence in Egypt, OPR-107, Directorate of intelligence, Office of Political Research, February 1975, k. 5, 10 https://www.cia.gov/library/readingroom/docs/CIA-RDP86T00608 R000600150002-9.pdf (14.01.2020); idem, Soviet Aid to and Presence in Iraq, No. 1613/66, 25 October 1966 [PDF], k. 4 https://www.cia.gov/library/readingroom/document/cia-rdp79t00826a001400010005-5 (20.01.2020); Department of the Army, Syria: A country study, (red. T. Collelo), Library of Congress, Federal Research Division, Washington April 1987, s. 266; B.D. Porter, The USSR in Third World Conflicts: Soviet Arms and Diplomacy in Local Wars 19451980, Cambridge-New York-Melbourne-Sydney 1988, s. 18; M.N. Kaatz, Sanaa and the Soviets, „Problems of Communism", January-February 1984, s. 26-28; В.И. Феськов, К.А. Калашников, В.И. Голиков, Советская Армия в годы «холодной войны» (1945-1991), Изд. Том. ун-та, Томск 2004, s. 180; S. M. Walt, The Origins of Alliances, Ithaca-London 1987, s. 106; А. Окороков, Сверхсекретные войны СССР. Первая полная энциклопедия, Москва 2010, s. 72-75, 79; The Military Balance 1990-1992, London 1990, s. 43; The Military Balance 1991-1992, London 1991, s. 45.

10 Vide: C. Andrew, W. Mitrochin, Archiwum Mitrochina II..., s. 174, 236; L. Pawlikowicz, Tarcza i miecz - od rozkwitu do upadku. Podstawowe funkcje, struktury, potencjat kadrowy oraz obsada personalna Komitetu Bezpieczeństwa Państwowego (przy Radzie Ministrów) ZSRR w latach 1975-1991, „Aparat Represji w Polsce Ludowej 1944-1989", nr 1 (10) / 2012, s. 29; История отечественных спецслужб и правоохранительных органов: 2-е Главное управление (http:// shieldandsword.mozohin.ru/kgb5491/structure/2GU.htm (18.01.2020). Wiadomo, że tzw. tajne wejścia miały miejsce w przypadku ambasad syryjskiej i egipskiej. C. Andrew, W. Mitrochin, Archiwum Mitrochina II..., s. 174

${ }^{11}$ Vide: L. Pawlikowicz, Aparat centralny 1. Zarzadu Glównego KGB jako instrument realizacji globalnej strategii Kremla 1954-1991, Warszawa 2013, s. 167-168, 171-173, 176-177, 280-281; История отечественных...: 1-е Главное управление http://shieldandsword.mozohin.ru/kgb5491/structure/1GU.htm (18.01.2020). 
i Afganistanu) przekroczyła 100 (oprócz tego operowało tam niemal 50 oficerów Głównego Zarządu Wywiadowczego (ros. Главное разведьвательное управление - ГРУ). Stany liczbowe poszczególnych rezydentur zależały od potencjału danego kraju oraz jego zarówno bieżącego, jak i długofalowego znaczenia dla Związku Radzieckiego (np. w latach siedemdziesiątych w ówczesnej ambasadzie radzieckiej w Jemenie Północnym służyło zaledwie kilku oficerów KGB, natomiast w analogicznej placówce w Egipcie po wojnie sześciodniowej ich liczba wzrosła nawet do 50) ${ }^{12}$.

Relatywnie niski potencjał naukowo-techniczny państw bliskowschodnich wpływał na niemal zupełny brak obecności operujących z terenu wspomnianych ekspozytur oficerów linii „X” (ds. wywiadu naukowo-technicznego). Z kolei funkcjonariusze linii „PR” (ds. wywiadu politycznego), poza pozyskiwaniem szerokiego spektrum informacji, głownie politycznych, ale także - choć w mniejszym zakresie - ekonomicznych i wojskowych, utrzymywali też kanały łączności i finansowania dla działających tam proradzieckich partii komunistycznych (przez większość analizowanego okresu działających nielegalnie). Natomiast ochrona kontrwywiadowcza placówek dyplomatycznych, w tym samych rezydentur, jak również zdobywanie danych o miejscowych służbach specjalnych, a w przypadku przedstawicielstw KGB podległych 20. Wydziałowi i zlokalizowanych w Syrii, Iraku oraz Południowym Jemenie również ograniczona wymiana informacji (z wyżej wymienionymi służbami) na temat zachodnich struktur wywiadowczych należały do pionu „KR” (ds. kontrwywiadu zagranicznego) ${ }^{13}$.

Spośród zidentyfikowanych osobowych źródeł informacji KGB na Bliskim Wschodzie niewątpliwie najważniejszym był Sami Szaraf, który w 1959 r. z pozycji asystenta ówczesnego szefa rządu, Gamala Nasera, awansował na stanowisko dyrektora Biura Informacji Premiera, a w czerwcu 1961 r. objął stanowisko ministra stanu ds. kontroli nad służbami specjalnymi w Kancelarii Prezydenta i sprawował je do maja 1971 r. ${ }^{14}$ W książce Mitrochina - obejmującej jedynie część danych z jego archiwum (pozostałe informacje nadal pozostają tajne), które również nie zawierało wszystkich osobowych źródeł informacji KGB

\footnotetext{
12 Vide: L. Pawlikowicz, Organizacja, zadania oraz wybrane problemy funkcjonowania legalnych rezydentur zagranicznych wywiadu KGB w latach 1954-1991, „Przegląd Bezpieczeństwa Wewnętrznego”, s. 141-142, 146-149; AIPN [Archiwum Instytutu Pamięci Narodowej], sygn. IPN 01538/9, Raport CIA , Wywiad Radziecki - KGB i GRU”, październik 1984 r., k. 97. W latach siedemdziesiątych i osiemdziesiątych udział oficerów KGB w stosunku do całego personelu danej placówki dyplomatycznej wahał się od 30 do $45 \%$ (kolejne 15-20\% stanowili funkcjonariusze GRU). W pozostałych instytucjach wykorzystywanych jako „przykrycie” do prowadzenia działalności operacyjnej przez 1. Zarząd Główny był zwykle niższy. Vide: O. Gordijewski, Ostatni przystanek - egzekucja, Warszawa 2001, s. 112; W. Suworow [W. Riezun], GRU: Radziecki wywiad wojskowy, Warszawa 1999, s. 131; W. Corson, R. Crowley, The New KGB: Engine of Soviet Power, New York 1985, s. 483.

${ }^{13}$ Vide: L. Pawlikowicz, Organizacja, zadania..., s. 136-139; История отечественных...: Tиповая структура резидентуры КГБ http://shieldandsword.mozohin.ru/kgb5491/resident/resident.htm (18.01.2020); AIPN, sygn. IPN 01538/9, Raport CIA ..., k. 97-99; C. Andrew, O. Gordijewski, KGB, Warszawa 1997, s. 652; C. Andrew, W. Mitrochin, Archiwum Mitrochina II..., s. 188 i n.; А. Колпакиди, Д. Прохоров, Внешняя разведка России, Санкт-Петербург-Москва 2001, s. 82-83.

14 Vide: J. Barron, KGB. Tajna dziatalność sowieckich agentów, Warszawa 1991, s. 69-71; C. Andrew, W. Mitrochin, Archiwum Mitrochina II..., s. 181-182, 188-191, 561; A. Goldschmidt, Biographical Dictionary of Modern Egypt, Boulder-London 2000, s. 189; G. Nkrumah, Sami Sharaf: Shadows of the revolution, „AlAhram Weekly Online", nr 546 z 15.08.2000 http://weekly.ahram.org.eg/2001/546/profile.htm (21.01.2017).
} 
operujących na terytorium owych 13 państw regionu - wymieniono nazwiska lub pseudonimy m.in. pięciu źródeł w kręgach miejscowych ministerstw spraw zagranicznych, siedmiu w szeroko rozumianych pozostałych resortach rządowych (bez MSZ), siedmiu w cywilnych i wojskowych służbach specjalnych oraz pięciu w siłach zbrojnych. Uzupełniali je agenci i kontakty poufne działający w ,establishmentowych" partiach politycznych, kręgach środków masowego przekazu oraz miejscowych, przychylnych Kremlowi, partiach komunistycznych. Charakterystyczne, że w wyżej wymienionej monografii wspomniano jedynie o obywatelach Egiptu, Libanu, Syrii, Iraku oraz Północnego i Południowego Jemenu, nie przytoczono natomiast jakichkolwiek danych o źródłach wśród obywateli Jordanii, Omanu i państw Zatoki Perskiej. Z kolei najwięcej informacji na temat osobowych źródeł informacji KGB, operujących na terytorium pierwszych sześciu krajów, odnosi się do Syrii. Jednakże trudno na tej podstawie formułować zbyt daleko idące wnioski co do ewentualnego ,rankingu” najbardziej spenetrowanych krajów regionu ${ }^{15}$.

Ponadto na Bliskim Wschodzie nader aktywnie i - ze względu na odbiegającą od poziomu rozwiniętych państw kapitalistycznych niższą efektywność pracy ówczesnych służb specjalnych państw tego regionu - relatywnie nieco bardziej skutecznie działał pion dezinformacji, który w strukturach komitetu znalazł się dopiero pod koniec lat pięćdziesiątych jako tzw. Wydział „D”, a kilka lat później rozwinięto go w tzw. Służbę „A”16.

Nadal natomiast brakuje większej liczby danych o operacjach pionu wywiadu nielegalnego KGB mających miejsce w krajach opisywanego regionu, choć wiadomo, że dość często podróżowali tam ,nielegałowie” Zarządu „S” operujący pod przykrywką obywateli państw należących do NATO (Stanów Zjednoczonych, Kanady, Austrii czy Turcji) oraz krajów neutralnych (np. Finlandii) ${ }^{17}$. W literaturze przedmiotu opisano jedynie dwa przypadki (w tym jednego małżeństwa), których pobyt w krajach Bliskiego Wschodu trwał co najmniej

\footnotetext{
${ }^{15}$ Vide: C. Andrew, W. Mitrochin, Archiwum Mitrochina II..., s. 180 i n.

${ }^{16}$ L. Pawlikowicz, Aparat centralny..., s. 223-232; История отечественных...: Отдел «Д» - Служба «А» http://shieldandsword.mozohin.ru/kgb5491/structure/1GU/A.htm (18.01.2020). Wszelako spośród wielu operacji dezinformacyjnych 1. Zarządu Głównego KGB w regionie do tych, które przyniosły „mierzalne” efekty, zaliczano w monografii Mitrochina jedynie trzy: doprowadzenie do oskarżenia w 1964 r. pewnej grupy syryjskich oficerów o szpiegostwo na rzecz Stanów Zjednoczonych, w 1972 r. niektórych odłamów prozachodniej opozycji w Iraku doprowadzenie do oskarżenia o szpiegostwo na rzecz Wielkiej Brytanii i Iranu, a w 1976 r. spowodowanie dymisji proamerykańskiego sekretarza prezydenta Sadata ds. zagranicznych Aszrafa Marwana. Vide: C. Andrew, W. Mitrochin, Archiwum Mitrochina II..., s. 194-195, 209, 230-231.

${ }^{17}$ Można tu wymienić choćby np. pobyty Jurija Nikołajewicza Loginowa - w Libanie i Egipcie (w 1964 r.), Wiktora Iwanowicza Gołowki (ps. „Graczow”) - w Libanie, Egipcie i Jordanii (w latach 1973-1974 oraz w 1977 r.) czy Anatolija Andriejewicza Tonkonoga (ps. „Tanow”) i Jeleny Timofiejewnej Fjodorowej (ps. „Tanowa”) - w Libanie, Kuwejcie i Syrii (kilkukrotnie pomiędzy ok. 1970 r. a 1982 r.). Vide: D. Wise, Molehunt: The Secret Search for Traitors That Shattwered the CIA, New York 1992, s. 171172, 214-219, 230-232; T. Mangold, Cold Warrior James Jesus Angleton: The CIA's Master Spy Hunter, London-Sydney-New York 1991, s. 1-8, 186-204, 252, 332; Raggruppamento Operativo SpecialeCarabinieri Reparto Anti Eversione n. 556/6, Alla Procuradella Repubblica Presso il Tribunale di Roma, Si trasmette il materiale documentale prodotto dal SISMI in data 08.10.1999, Fonte delicata, Rapporto Impedian numero 185, Data di emissione : 22 aprile 1997, Oggetto: „Grachev” (Viktor Ivanovich Golovko - Olavi Toivonen) illegale del KGB http://www.cooperweb.it/societaeconflitto/Mitrokhin4.html (05.01.2020); Wilson Center - Digital Archive International History Declassified: The Tanov Case [Folder 43] http://digitalarchive.wilsoncenter.org/ document/110344 (21.01.2017).
} 
rok. Wykorzystywano je jednak przede wszystkim do prowadzenia działalności przeciwko państwom południowej części Europy oraz Japonii ${ }^{18}$.

\section{KONTAKTY MIĘDZY OFICERAMI KGB A CZLONKAMI BLISKOWSCHODNICH ORGANIZACJI TERRORYSTYCZNYCH}

Zapewne najwięcej kontrowersji - nie tylko względu na reminiscencje do obecnej sytuacji międzynarodowej - odnosi się do charakteru kontaktów pomiędzy oficerami pionu dywersji a rozmaitymi radykalnymi palestyńskimi strukturami, które - według ówczesnych i dzisiejszych standardów świata zachodniego - można zaliczyć do organizacji terrorystycznych, natomiast zgodnie z ideologiczną terminologią Kremla określano je mianem ruchów „narodowowyzwoleńczych” („национально-освободительных”).

Mimo że zgodę na wykorzystanie przez KGB tego typu struktur (nie tylko zresztą o proweniencji arabskiej, lecz także latynoamerykańskiej czy rozmaitych odłamów lewackoeuropejskich) Komitet Centralny KPZR wydał jeszcze w sierpniu 1961 r., to kontakty wyraźnie zdynamizowano trzy lata później wraz ze znaczącym zwiększeniem przez Biuro Polityczne KC KPZR wydatków przeznaczonych na pomoc w ich wyszkoleniu i uzbrojeniu ${ }^{19}$. Ze względu na skalę przedsięwzięcia i związane $\mathrm{z}$ tym problemy logistyczne do operacji zaangażowano także GRU, przy czym w ramach uzgodnionego podziału zadań 1. Zarząd Główny KGB miał zapewnić kanały łączności, środki finansowe oraz zagraniczne modele broni, wywiad wojskowy natomiast był odpowiedzialny za szkolenie i dostawy dużych transportów broni (realizowanie drogą morską) ${ }^{20}$. Utrzymanie w tajemnicy operacji o tak szerokim zasięgu nie było jednak możliwe. Według danych Centralnej Agencji Wywiadowczej w szczytowym pod tym względem 1977 roku GRU i (w mniejszym stopniu) KGB zorganizowały w samym Związku Radzieckim na rzecz różnego rodzaju grup „narodowo-wyzwoleńczych” oraz skrajnie lewicowych organizacji terrorystycznych aż 35 kursów instruktażowych.

Najczęściej szkolenia przeprowadzano w obozach wojskowych zlokalizowanych w miejscowości Bałaszycha oraz nad jeziorem Istra nieopodal Moskwy, w Sanprobal koło

\footnotetext{
${ }^{18} \mathrm{~W}$ pierwszym przypadku dotyczy to Aszota Abgarowicza Akopiana (ps. „Jefrat”) i Kiry Wiktorownej Czertienko (ps. „Tania”), którzy od początku 1953 do 1954 r. przebywali w Kairze, a uprzednio (pomiędzy październikiem 1948 r. a końcem 1952 r.) i następnie (w latach 1954-1959) rezydowali w Rzymie. W drugim odnosi się natomiast do Szamila Abdullazjanowicza Chamzina (ps. „Chalef”), którego pobyt w Arabii Saudyjskiej trwał od początku 1973 r. do połowy 1974 r., ale wcześniej przez 12 lat przebywał w Japonii. Vide: Raggruppamento Operativo SpecialeCarabinieri..., Rapporto Impedian numero 165, Data di emissione: 16 maggio 1996, Oggetto: Residentura illegale del KGB in Italia diretta da „Yefrat” e „Tanya”: Ashot Abgarovich Akopyan alias Oganess Saradzhan e Kira Vitkorovna Akopyan http://www.cooperweb.it/ societaeconflitto/Mitrokhin4.html (05.01.2012); C. Andrew, W. Mitrochin, Archiwum Mitrochina: KGB w Europie i na Zachodzie, Warszawa 2001, s. 512, 832-833; Wilson Center - Digital Archive International History Declassi-fied: An Illegal Trainer. KGB History af agent "Halef" [Folder 60] http://digital archive.wilsoncenter.org/document/110708 (21.01.2020).

${ }^{19}$ C. Andrew, W. Mitrochin, Archiwum Mitrochina ..., s. 646-647; C. Andrew, W. Mitrochin, Archiwum Mitrochina II..., s. 73; C. Sterling, Sieć terroru. Prawda o międzynarodowym terroryzmie, Warszawa 1990, s. 20, 40.

${ }^{20} \mathrm{~S}$. Lunev, I. Winkler, Through the Eyes of the Enemy: Russia's highest ranking military defector reveals why Russia is more dangerous than ever, Regnery Publ., Washington 1998, s. 80; Central Intelligence Agency, Soviet Support for International Terrorism and Revolutionary Violence, SNIE 11/2-81, 27 May 1981, k. 27, https://www.cia.gov/library/readingroom/docs/DOC_0000272980.pdf (21.01.2017).
} 
Symferopola, w Żółtych Wodach niedaleko Kriwego Rogu, w okolicach Odessy oraz w Marach tuż przy granicy z Iranem. Podobne kursy odbywano - korzystając z pośrednictwa „bratnich” służb (głównie wojskowych) - także na terytorium większości pozostałych państw Układu Warszawskiego, przy czym najwięcej zidentyfikowano ich w NRD (8), Czechosłowacji i Bułgarii (po 4) oraz Polsce (3). Zdecydowana większość szkolonych w nich terrorystów wywodziła się spośród trzech formacji palestyńskich: Organizacji Wyzwolenia Palestyny, Ludowego Frontu Wyzwolenia Palestyny oraz Demokratycznego Frontu Wyzwolenia Palestyny ${ }^{21}$. Mimo że według danych CIA jeszcze w 1981 r. stale w jednym czasie przebywało we wspomnianych ośrodkach na terytorium ZSRR ok. 2000 Palestyńczyków ${ }^{22}$, to skala radzieckiego zaangażowania w tym zakresie uległa po $1982 \mathrm{r}$. zauważalnej redukcji. Wydaje się, że przesądziły o tym dwa czynniki: potencjalne wysokie koszty wizerunkowe będące następstwem częściowo ujawnianych, począwszy od chwili dokonanego w maju 1981 r. zamachu na papieża Jana Pawła II, wzmianek związanych $\mathrm{z}$ istnieniem na terytorium Związku Radzieckiego i innych państw Bloku Radzieckiego wspomnianych obozów szkoleniowych ${ }^{23}$, a także przeniesienie (po zajęciu w czerwcu $1982 \mathrm{r}$. południowego Libanu przez siły zbrojne Izraela) kwatery głównej OWP z Bejrutu do Tunisu, co doprowadziło do większego odizolowania jej struktur kierowniczych od Strefy Gazy i zachodniego Brzegu Jordanu, gdzie zamieszkiwała większość Palestyńczyków.

Stopień kontroli 1. Zarządu Głównego nad działalnością tych organizacji był jednak nader zróżnicowany. W przypadku najbardziej „zaufanych” - w szczególności Ludowego Frontu Wyzwolenia Palestyny - poprzez stojącego na jego czele agenta KGB, dr. Wadi Haddada, ,przedstawiciele” KGB nie tylko wpływali na wybór potencjalnych celów, lecz także udzielali wskazówek co do najskuteczniejszych metod i sposobów ich realizacji ${ }^{24}$. Choć tak bliskie relacje należały do wyjątków, to wykorzystując dostępne kontakty oficerowie komitetu byli w stanie pozyskać sygnały o planowanych zamachach drogą półoficjalną lub tajną poprzez własne osobowe źródła informacji, przy czym do ich łącznikowania wykorzystywano nie tyle funkcjonariuszy pionu dywersji - funkcjonującego od października 1965 r. w ramach Wydziału „W”, a następnie od kwietnia 1976 r. w strukturach 8. Wydziału Zarządu „S”, ile specjalizujących się w bieżącym monitorowaniu organizacji terrorystycznych oficerów kontrwywiadu zagranicznego działającego wówczas w strukturach tzw. Służby nr 2, a następnie od 1972 r.

\footnotetext{
${ }^{21}$ C. Sterling, Sieć terroru..., s. 304-305; Л. Млечин, Особая папка: Служба внешней разведки. Самыле знаменитые операции советской и российской разведки, Яуза-Эксмо, Москва 2000, s. 150-151; C. Andrew, O. Gordijewski, KGB..., s. 478; S. Lunev, I. Winkler, Through the Eyes..., s. 80; Central Intelligence Agency, Soviet Support for International Terrorism... 27 May 1981..., k. 27 https://www.cia.gov/library/ readingroom/docs/DOC_0000272980.pdf (21.12.2019); AIPN, sygn. IPN 01538/9, Raport CIA „Wywiad Radziecki-KGB i GRU”,..., k. 122; USSR Facts \& Figures Annual, Vol. 10, 1986 (red. J.L. Scherer), Academic International Press, Gulf Breeze 1986, s. 340.

${ }^{22}$ J. Maury, The KGB's Terrorist Footprints, „Washington Post” z 3.09.1981 r., s. A 27.

${ }^{23}$ Ibidem.

${ }^{24}$ C. Andrew, W. Mitrochin, Archiwum Mitrochina II..., s. 283-284.
} 
(po jej podniesieniu do rangi zarządu) w Zarządzie „,K”25. Z drugiej strony różnorodność rozmaitych frakcji palestyńskich oraz ich nierzadko wzajemnie sprzeczne ambicje doprowadzały niekiedy do sytuacji, gdy 1. Zarząd Główny z pozycji gracza staczał się do roli rozgrywanego. Przykładem było m. in. uprowadzenie w końcu września 1985 r. czterech osób personelu dyplomatycznego (w tym dwóch oficerów komitetu) z radzieckiej ambasady w Bejrucie, jednak w rezultacie ,interwencji” przybyłej ze Związku Radzieckiego grupy wojskowego oddziału operacji specjalnych „Wympieł” uwolniono trzech pozostałych przy życiu zakładników, a podobne przypadki porwań już się nie powtórzyły ${ }^{26}$.

\section{POTENCJALNE IMPLIKACJE DZIAŁALNOŚCI KGB NA BLISKIM WSCHODZIE W OKRESIE PORADZIECKIM}

Po rozpadzie Związku Radzieckiego nowe rosyjskie służby specjalne, zwłaszcza odpowiedzialna za wywiad zagraniczny SWR przejęła bliskowschodnie aktywa byłego KGB. Mimo upływu czasu ich wartość ma nadal istotne znaczenie, o czym przekonano się, gdy 8 września 2016 r. dwoje izraelskich badaczy zatrudnionych na Uniwersytecie Jerozolimskim, dr Isabella Ginor oraz Gideon Remez, ujawniło dwuwersowy zapisek udostępniony im kilka dni wcześniej w Churchill College w Cambridge, gdzie przechowywane są zapiski Mitrochina (włącznie z danymi objętymi klauzulą tajności). Jego treść brzmiała następująco: „«Krotow» - Abbas Mahmud, ur. w 1935 r. w Palestynie, członek komitetu Wykonawczego OWP Fatah w Damaszku, agent KGB"27. Wspomniane dane odnosiły się do działacza Organizacji Wyzwolenia Palestyny, którego szczyt kariery przypadł już na erę postzimnowojenną. W marcu 2003 r. Mahmud Abbas został pierwszym premierem Autonomii Plestyńskiej, od października 2004 r. zastąpił Jasira Arafata na stanowisku przewodniczącego OWP, by ostatecznie w styczniu 2013 r. sięgnąć po tytuł prezydenta Palestyny ${ }^{28}$. Choć nie dysponujemy wiedzą, w jakim dokładnie okresie Abbas współpracował z KGB oraz czy i kiedy Rosjanie byli w stanie uzyskać informację, że „Krotow” znajdował się w zapiskach Mitrochina, to przykład ten potwierdza, że wartość poszczególnych osobowych źródeł informacji byłego KGB wcale nie musiała - wraz z upływem czasu - maleć.

Otwartą pozostaje także kwestia, na ile metody stosowane przez KGB w celu pozyskiwania informacji od członków ugrupowań terrorystycznych czy ich inspirowania

\footnotetext{
25 О. Калугин, Прошай, Лубянка! Олимп, Москва 1995, s. 161; А. Колпакиди, Д. Прохоров, Внешняя разведка России..., s. 70; Д. Прохоров, Разведка от Сталина.., s. 104-105; J. Barron, KGB dzisiaj: Niewidzialna ręka, Volumen, Warszawa 1991, s. 351. Wiadomo, że naczelnikiem owego pionu - 4. Wydziału Zarządu „K” - był w okresie największego nasilenia pomocy udzielanej przez 1. Zarząd Główny strukturom OWP (na przełomie lat siedemdziesiątych i osiemdziesiątych) płk. Oleg Nieczyporienko, którego m. in. dekadę wcześniej wydalono z Meksyku za udział w spisku próbie zbrojnego obalenia tamtejszego rządu. Zob. szerzej: J. Barron, KGB. Tajna działalność..., s. 245-268.

${ }^{26}$ Vide: L. Pawlikowicz, Aparat centralny..., s. 320-321.

27 Reuters: J. Heller, Palestinian leader Abbas was KGB spy in 1980s: Israeli researchers, 8 September 2016, https://www.reuters.com/article/us-israel-palestinians-abbas/palestinian-leader-abbas-was-kgb-spy-in-1980sisraeliresearchers-idUSKCN11E1U0 (21.12.2019). Zamieszczono tam również fotokopię wspomnianego zapisu.

${ }^{28}$ Who's Who in the Arab World 2007-2008, München 2007, s. 1142-1143.
} 
w ostatnich dwóch dekadach zimnej wojny mogą być przydatne do analogicznych celów w dobie współczesnej wojny z terroryzmem, np. w walce z ISIS, tym bardziej, że według danych zachodnich służb specjalnych w 2017 roku spośród cudzoziemców wyznania muzułmańskiego walczących w szeregach tej formacji najwięcej - obok Tunezyjczyków (ok. 6000) - było byłych obywateli rosyjskich (ok. 5000-7000) $)^{29}$.

\section{WNIOSKI}

Analogicznie do operacji podejmowanych w każdym zakątku globu struktury Komitetu Bezpieczeństwa Państwowego (przy Radzie Ministrów) ZSRR, w ramach których prowadzono działalność na terytorium państw Bliskiego Wschodu, zdecydowaną większość informacji pozyskiwały poprzez działania 1. Zarządu Głównego (ds. wywiadu zagranicznego) KGB, jak również 8. Zarządu Głównego (ds. kryptografii i dekryptażu) KGB, a następnie 16. Zarządu (ds. wywiadu sygnałowego) KGB. Jednakże w przeciwieństwie do innych regionów świata do specyfiki charakterystycznej dla Bliskiego Wschodu należy zaliczyć znacznie większą rolę odgrywaną przez 3. Zarząd Główny (ds. kontrwywiadu wojskowego) KGB, a w zakresie działań podejmowanych w ramach 1. Zarządu Głównego KGB faktyczny brak struktur wywiadu naukowo-technicznego, korzystniejsze otoczenie w odniesieniu do przedsięwzięć podejmowanych w zakresie działań dezinformacyjnych, relatywnie mniejsze (według wszelkiego prawdopodobieństwa) nasycenie regionu „nielegałami” oraz mniej lub bardziej udane próby wykorzystania (poprzez piony dywersji i kontrwywiadu zagranicznego) organizacji terrorystycznych (w zamian za dostarczanie środków finansowych i broni) do ataków na cele mieszczące się w kategorii uznawanej przez obie strony za „,wspólnego wroga", a odnoszonego do szeroko rozumianego Zachodu.

W dobie postzimnowojennej aktywa, a być może także metody pozyskiwania informacji od organizacji terrorystycznych lub ich inspirowania mogły odnaleźć swój „renesans”.

\section{BIBLIOGRAFIA}

AIPN [Archiwum Instytutu Pamięci Narodowej], październik 1984 r., Raport CIA „Wywiad Radziecki - KGB i GRU”, sygn. IPN 01538/9.

Andrew Christopher, Gordijewski Oleg. 1997. KGB. Warszawa: Bellona.

Andrew Christopher, Mitrochin Wasilij. 2001. Archiwum Mitrochina: KGB w Europie i na Zachodzie. Warszawa: Wyd. Literackie „Muza” S.A.

Andrew Christopher, Mitrochin Wasilij. 2006. Archiwum Mitrochina II: KGB i świat. Poznań: Dom Wydawniczy „Rebis”.

\footnotetext{
${ }^{29}$ Mniej cudzoziemskich ochotników wywodziło się nawet $\mathrm{z}$ takich krajów jak Arabia Saudyjska (ok. 2500), Turcja (ok. 2100) czy Jordania (ok. 2000). Zob.: I. Bremmer, The Top 5 Countries Where ISIS Gets Its Foreign Recruits, „Time”, 14.04.2017 r., https://time.com/4739488/isis-iraq-syria-tunisia-saudi-arabiarussia/ (29.01.2020).
} 
Ball Desmond. 1989. Soviet Signals Intelligence (SIGINT). Canberra: Australian National University, Strategic and Defence Studies-Centre Research School of Pacific Studies.

Barron John. 1991. KGB dzisiaj: Niewidzialna ręka. Warszawa: Volumen.

Barron John. 1991. KGB: Tajna działalność sowieckich agentów. Warszawa: Volumen.

Bremmer Ian. 2017. „The Top 5 Countries Where ISIS Gets Its Foreign Recruits”, Time, https://time.com/4739488/isis-iraq-syria-tunisia-saudi-arabia-russia/.

Central Intelligence Agency. 1956. Annex to Watch Committee Report No. 319, SC 00358/56, https://history.state.gov/historicaldocuments/frus1955-57v16/d214.

Central Intelligence Agency. 1975. Soviet Military Presence in Egypt, OPR-107, Directorate of intelligence, Office of Political Research, https://www.cia.gov/library/ readingroom/docs/CIA-RDP86T00608R000600170001-8.pdf.

Central Intelligence Agency. 1966. Soviet Aid to and Presence in Iraq, No. 1613/66, https://www.cia.gov/library/readingroom/docs/CIA-RDP79T00826A001400010005-5.pdf.

Central Intelligence Agency. 1981. Soviet Support for International Terrorism and Revolutionary Violence, https://www.cia.gov/library/readingroom/docs/DOC_0000272980.pdf.

Collelo Thomas (Ed.). 1987 Syria: A country study. Washington: Department of the Army, Library of Congress-Federal Research Division.

Corm Georges. 2003. Bliski Wschód w ogniu: Oblicza konfliktu 1956-2003. Warszawa: Dialog. Corson William R., Crowley Robert T. 1985. The New KGB: Engine of Soviet Power, New York: William Morrow \& Co.

Feskov Vitaliy I., Kalashnikov Konstantin A., Golikov Valeriy I. 2004. Sovetskaya Armiya v gody «kholodnoy voyny» (1945-1991). Tomsk: Izdatel'stvo Tomskogo Universiteta [PDF].

Golan Galia. 1991. Soviet Policies in the Middle East: From World War II to Gorbachev. Cambridge-New York-Melbourne-Sydney: Cambridge University Press.

Goldschmidt Arthur. 2000. Biographical Dictionary of Modern Egypt. Boulder-London: Lynne Rienner.

Gordijewski Oleg. 2001. Ostatni przystanek-egzekucja, Warszawa: Bellona.

Heller Jeffrey. 2016. Palestinian leader Abbas was KGB spy in 1980s: Israeli researchers.

Reuters. 8 September 2016, https://www.reuters.com/article/us-israel-palestiniansabbas/palestinian-leader-abbas-was-kgb-spy-in-1980s-israeli-researchersidUSKCN11E1U0.

Istoriya otechestvennykh spetssluzhb i pravookhranitel'nykh organov. 2020. 1-ye Glavnoye upravleniye, http://shieldandsword.mozohin.ru/kgb5491/structure/1GU.htm

Istoriya otechestvennykh spetssluzhb i pravookhranitel'nykh organom. 2020. 2-ye Glavnoye upravleniye http:// shieldandsword.mozohin.ru/kgb5491/structure/2GU.htm.

Istoriya otechestvennykh spetssluzhb i pravookhranitel'nykh organom.2020. Otdel «D»Sluzhba «A», http://shieldandsword.mozohin.ru/kgb5491/structure/1GU/A.htm.

Istoriya otechestvennykh spetssluzhb i pravookhranitel'nykh organom. 2020. Tipovaya struktura rezidentury KGB. http://shieldandsword.mozohin.ru/kgb5491/resident/resident.htm.

Kaatz Mark N. 1984. „Sanaa and the Soviets”. Problems of Communism 33(1): 21-34.

Kalugin Oleg. 1995. Proshay, Lubyanka! Moskva: Olimp.

Knight Amy. 1988. The KGB : Police and Politics in the Soviet Union, Boston-LondonSydney: Unwin Hyman. 
Kokurin Aleksandr I., Petrov Nikita V. (Ed.). 2003. Lubyanka. Organy VChK-OGPUNKVD-NKGB-MGB-MVD-KGB 1917-1991. Spravochnik. Moskva:

Mezhdunarodnyy Fond «Demokratiya».

Kolpakidi Aleksandr I., Prokhorov Dmitriy P. 2001. Vneshnyaya razvedka Rossii. SanktPeterburg-Moskva: Neva-Olma-Press.

Lunev Stanislav, Winkler Ira, 1998. Through the Eyes of the Enemy: Russia's highest ranking military defector reveals why Russia is more dangerous than ever. Washington: Regnery Publ.

Maury Jack, 1981. „The KGB's Terrorist Footprints”. Washington Post. 27.09.1981: A 27 [PDF].

Nkrumah Gamal. 2000. „Sami Sharaf: Shadows of the revolution”. Al-Ahram Weekly Online, no 546 In http://weekly.ahram.org.eg/2001/546/profile.htm

Mangold Tom. 1991. Cold Warrior James Jesus Angleton: The CIA's Master Spy Hunter. London-Sydney-New York: Simon \& Schuster.

The Military Balance 1990-1991. 1990. London: International Institute for Strategic Studies.

The Military Balance 1991-1992. 1991. London: International Institute for Strategic Studies.

Mlechin Leonid M. 2004. Osobaya papka: Sluzhba vneshney pazvedki. Samyye znamenityye operatsii sovetskoy i rossiyskoy razvedki. Moskva: Yauza-Eksmo.

Okorokov Aleksandr. 2010. Sverkhsekretnyye voyny SSSR: Pervaya polnaya entsiklopediya. Moskva: Yauza-Eksmo.

Pawlikowicz Leszek. 2013. Aparat centralny 1. Zarządu Głównego KGB jako instrument realizacji globalnej strategii Kremla 1954-1991. Warszawa: Oficyna Wydawnicza „Rytm”-Bellona.

Pawlikowicz Leszek. 2013. „Organizacja, zadania oraz wybrane problemy funkcjonowania legalnych rezydentur zagranicznych wywiadu KGB w latach 1954-1991”. Przegląd Bezpieczeństwa Wewnętrznego - Wydanie Specjalne. Emów: Agencja Bezpieczeństwa Wewnętrznego-Ośrodek Studiów Wschodnich: 134-149.

Pawlikowicz Leszek. 2012. „Tarcza i miecz - od rozkwitu do upadku. Podstawowe funkcje, struktury, potencjał kadrowy oraz obsada personalna Komitetu Bezpieczeństwa Państwowego (przy Radzie Ministrów) ZSRR w latach 1975-1991”. Aparat Represji w Polsce Ludowej 1944-1989. Nr 1 (10)/2012: 11-83.

Pearcy George Etzel. 1964. The Middle East: An Indefinable Region, Washington: Department of State, Bureau of Public Affairs.

Porter Bruce D. 1988. The USSR in Third World Conflicts: Soviet Arms and Diplomacy in Local Wars 1945-1980. Cambridge-New York-Melbourne-Sydney: Cambridge University Press.

Prokhorov Dmitriy P. 2005. Razvedka ot Stalina do Putina. Sankt-Peterburg: Neva.

Raggruppamento Operativo Speciale Carabinieri Reparto Anti Eversione n. 556/6. 1999. Alla Procuradella Repubblica Presso il Tribunale di Roma, Si trasmette il materiale documentale prodotto dal SISMI in data 08.10.1999. Fonte delicata,

Rapporto Impedian numero 165, Data di emissione: 16 maggio 1996, Oggetto: Residentura illegale del KGB in Italia diretta da „Yefrat” e „Tanya”: Ashot Abgarovich Akopyan alias Oganess Saradzhan e Kira Vitkorovna Akopyan, http://www.cooperweb.it/ societaeconflitto/Mitrokhin4.html. 
Raggruppamento Operativo Speciale Carabinieri Reparto Anti Eversione n. 556/6. 1999. Alla Procuradella Repubblica Presso il Tribunale di Roma, Si trasmette il materiale documentale prodotto dal SISMI in data 08.10.1999. Fonte delicata,

Rapporto Impedian numero 185, Data di emissione: 22 aprile 1997, Oggetto: „Grachev” (Viktor Ivanovich Golovko - Olavi Toivonen) illegale del KGB, http://www.cooperweb.it/societaeconflitto/Mitrokhin4.html.

Scherer John L. (Ed,). 1986. USSR Facts \& Figures Annual. Vol. 10, Gulf Breeze: Academic International Press.

Sterling Claire. 1990. Sieć terroru: Prawda o międzynarodowym terroryzmie. Warszawa: Wyd. Głos.

Suworow Wiktor [Riezun Władimir]. 1999. GRU: Radziecki wywiad wojskowy. Warszawa: Adamski \& Bieliński.

Walt Stephen M. 1987. The Origins of Alliances. Ithaca-London: Cornell University Press.

Who's Who in the Arab World 2007-2008. 2007. München: K.G. Saur.

Wilson Center - Digital Archive International History Declassified. 2007. The Tanov Case [Folder 43], http://digitalarchive.wilsoncenter.org/document/110344.

Wilson Center - Digital Archive International History Declassified. 2007. An Illegal Trainer: KGB History af agent "Halef" [Folder 60], http://digitalarchive.wilsoncenter.org/ document/110708.

Wise David. 1992. Molehunt: The Secret Search for Traitors That Shattwered the CIA. New York: Random House. 